\title{
Synthesis and secretion of gonadotropins including structure-function correlates
}

\author{
George R. Bousfield • James A. Dias
}

Published online: 8 July 2011

(C) The Author(s) 2011. This article is published with open access at Springerlink.com

\begin{abstract}
The synthesis and secretion of the gonadotropic hormones involves coordination of signal transduction, gene expression, protein translation, post-translational folding and modification and finally secretion. The production of biologically active gonadotropin thus requires appropriately folded and glycosylated subunits that assemble to form the heterodimeric hormone. Here we overview recent literature on regulation of gonadotropin subunit gene expression and current understanding of the assembly and secretion of biologically active gonadotropic hormones. Finally, we discuss the therapeutic potential of understanding glycosylation function towards designing new forms of gonadotropins based on observations of physiologically relevant parameters such as age related glycosylation changes.
\end{abstract}

Keywords Transcription $\cdot \mathrm{FSH} \beta \cdot \mathrm{LH} \beta \cdot$ Common $\alpha$ subunit · GnRH

$\begin{array}{ll}\text { Abbreviations } & \\ \text { ASGP-R } & \text { Asialo-glycoprotein receptor } \\ \text { cAMP } & \text { cyclic AMP } \\ \text { CG } & \text { chorionic gonadotropin }\end{array}$

Supported by NIH grant R01HD18407 (JAD) and P01AG029531 (GRB).

G. R. Bousfield $(\bowtie)$

Department of Biological Sciences, Wichita State University, Wichita, KS, USA

e-mail: george.bousfield@wichita.edu

\section{J. A. Dias}

Department of Biomedical Sciences, School of Public Health,

University at Albany,

Albany, NY, USA
CRE

CREB

EGR1

ESI-MS

$\mathrm{FSH}$

FSHR

$\mathrm{Gn}_{2} \mathrm{M}_{8}$

$\mathrm{Gn}_{2} \mathrm{M}_{9} \mathrm{Glc}_{1}$

GnIH

GnRH

GPCR

HEK293

ICER

Isl-1

JNK1

LH

LHR

MALDI-TOF-MS

MEK1

MGAT

OST

PGF2 $\alpha$

PGI

PKC

PLC

SNARES

ST3Gal

ST6Gal

TGF $\beta$

$\mathrm{TSH}$
cAMP response element

CRE binding protein

early growth response 1 electrospray mass spectrometry Follicle-stimulating hormone FSH receptor N-acetyl-glucosamine2 Mannose8

$\mathrm{N}$-acetyl-glucosamine2 Mannose9 Glucose1

gonadotropin inhibitory hormone gonadotropin releasing hormone

$\mathrm{G}$ protein-coupled receptor human embryonic kidney 293 cell line induciblecAMP early repressor insulin gene enhancer protein Janus kinase 1

luteinizing hormone

LH receptor matrix-assisted laser desorption time-of-flight mass spectrometry mitogen activated protein kinase kinase 1

$\mathrm{N}$-Acetyl-glucosamine transferase oligosaccharyltransferase prostaglandin F $2 \alpha$ prostaglandin I protein kinase $\mathrm{C}$ phospholipase $\mathrm{C}$ soluble N-ethylmaleimide-sensitive attachment protein receptor $\alpha 2-3$-sialyltransferase $\alpha 2-6$-sialyltransferase transforming growth factor $\beta$ thyroid-stimulating hormone 


\section{Introduction}

The glycoprotein hormone family includes luteinizing hormone (LH), follicle-stimulating hormone (FSH), thyroid-stimulating hormone (TSH) and chorionic gonadotropin (CG) [1]. Production of these hormones occurs in either the pituitary (LH, FSH, TSH) [2] or by the chorion of a developing fetus (CG) [3, 4]. These hormones are heterodimeric, consisting of a common alpha subunit and a unique beta subunit (Fig. 1), and they are also glycosylated [5]. Therefore, their production requires coordination of transcriptional regulation of the subunit genes [6], translation of mRNA, post-translational processing and assembly, packaging and secretion.

\section{Regulation of the gonadotropin genes}

The canonical regulator of gonadotropin secretion is the hypothalamic decapeptide, GnRH, which can induce stimulus-secretion coupling as well as gene expression
[7]. However, it is clear now that many paths coalesce to achieve the complexity and disparate regulation of $\mathrm{LH}$ and FSH expression, a necessary first step to production and secretion. GnRH mediated gonadotropin secretion can be enhanced by the transcription factor Isl-1, which is elevated in response to $\mathrm{GnRH}$ as well as by activin and leptin stimulation, although the responses to activin and leptin were higher and more prolonged than that induced by GnRH. However, subsequent experiments indicated Isl-1 mainly is responsible for leptin-mediated $\mathrm{FSH} \beta$ and $\mathrm{LH} \beta$ production, not $\mathrm{GnRH}$ - or activin-mediated secretion, as knocking down Isl-1 expression had no significant effect on gonadotropin regulation by either GnRH or activin [8]. Despite this regulation, in marsupials, $\mathrm{LH} \beta$ gene expression is relatively unchanged despite widely variable levels of $\mathrm{LH}$ secretion, whereas $\mathrm{FSH} \beta$ gene expression covaries with level of FSH [9]. Thus, the secretion of LH appears to be induced, whereas the secretion of FSH is constitutive, as will be discussed below.

The release of GnRH from hypothalamic neurons is pulsatile [10]. Given the effect of $\mathrm{GnRH}$ as a releasing

\section{A. Alpha Subunits}

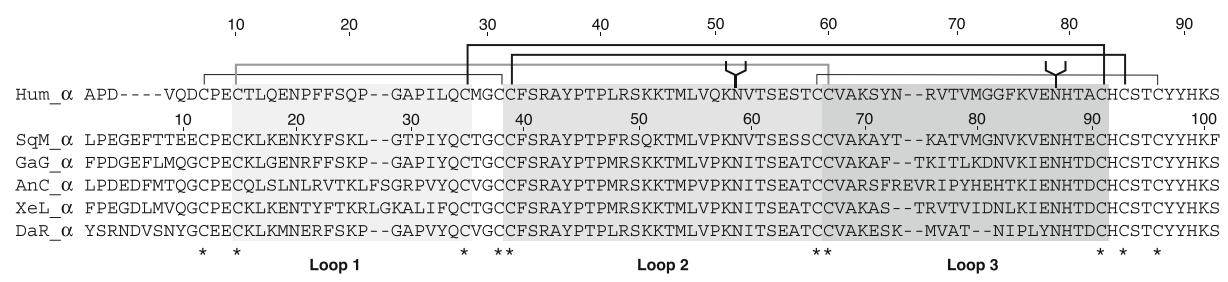

\section{B. LH, FSH, and CG Beta Subunits}

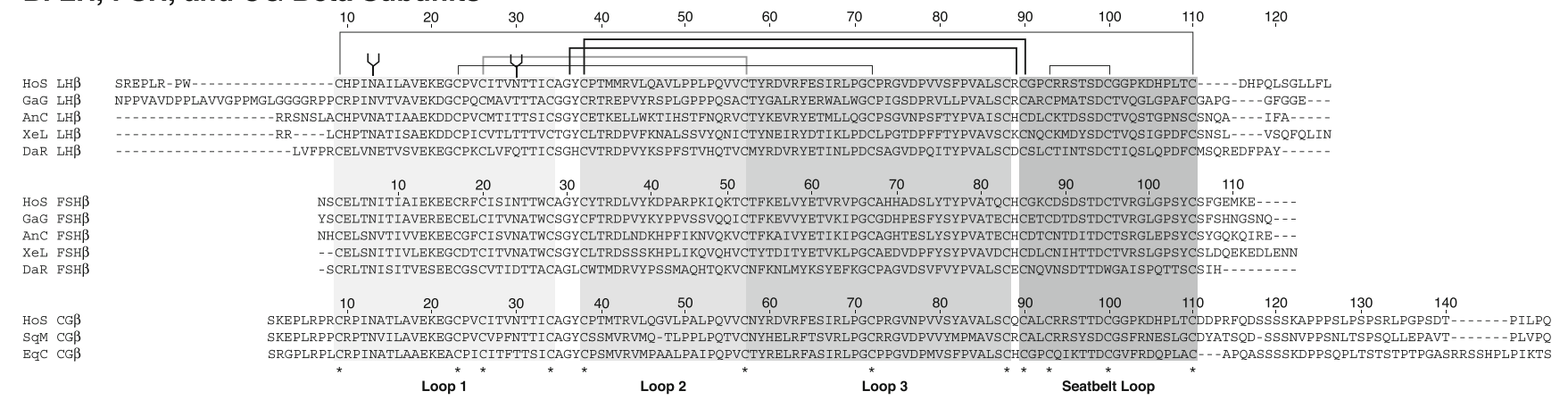

Fig. 1 Primary structures of vertebrate gonadotropins. The mature amino acid sequences for the human gonadotropin subunits and equine $\mathrm{LH} / \mathrm{CG} \beta$ are shown along with those predicted by the SignalP 3.0 Server (http://www.cbs.dtu.dk/services/SignalP/) for the primary structures translated from nucleotide sequences. The amino acid sequences were obtained from NCBI and represent selected vertebrate species: mammalian (Homo sapiens), avian (Gallus gallus), reptilian (Anolis carolinensis), amphibian (Xenopus laevis), and fish (Danio rerio) of clinical or scientific significance. The $D$. rerio $F S H \beta$ sequence is suspect because of the lack of potential cystine noose disulfide bond. The horse (Equus caballus) and squirrel monkey (Saimiri boliviensis boliviensis) $\mathrm{CG} \beta$ sequences were included to illustrate alternatives to the well known hCG $\beta$ primary structure and because they replace $\mathrm{LH} \beta$ in their respective species. Sequence alignments were made using the
NCBI tool, COBALT. The locations of N-glycans are indicated by the "tuning forks" above the glycosylation sites. Please note that while both FSH $\beta$ and hCG $\beta$ possess two N-glycans, most vertebrate $\mathrm{LH} \beta$ s are typically glycosylated at $\mathrm{Asn}^{13}$, while human $\mathrm{LH} \beta$ is glycosylated at $\mathrm{Asn}^{30}$. The human $\mathrm{CGb}$ is also O-glycosylated at 4 Ser residues 121, 127,132 , and 138. Squirrel monkey CG $\beta$ is N-glycosylated at $\mathrm{Asn}^{30}$ and O-glycosylation remains to be determined experimentally, although they are expected to be absent. The three loops created by the cystine knot motifs and the $\beta$-subunit seat belt loop are shaded and labeled. Cys residues are highlighted by asterisks under subunit sequence. A. Alpha subunit sequences illustrating the difference in numbering between the 92-residue human and other vertebrate 96-98-residue $\alpha$-subunit sequences. B. Beta subunit sequences grouped by hormone as follows: $\mathrm{LH} \beta$, $\mathrm{FSH} \beta$, and $\mathrm{CG} \beta$ 
hormone, one might expect that all secretagogues including GnRH would engender gene expression that would co-vary with pulse. When mouse pituitary gonadotrophs were stimulated with adenylate-cyclase-activating polypeptide there was no change in $\mathrm{LH} \beta$ or $\mathrm{FSH} \beta$ gene expression, although the common $\alpha$ subunit gene expression was induced [11]. Remarkably, perfusion of pulsatile doses of adenylate-cyclase-activating polypeptide engendered elevation of both the $\mathrm{LH} \beta$ and $\mathrm{FSH} \beta$ genes [11]. Although both $\mathrm{LH} \beta$ and $\mathrm{FSH} \beta$ gene expression was upregulated by pulsed administration of the peptide, high frequency pulses increased $\mathrm{LH} \beta$ gene expression more than $\mathrm{FSH} \beta$ gene expression whilst low frequency pulses had the opposite effect [11]. Thus, like GnRH, differential regulation of gonadotropin gene expression can be achieved by modulation of the signal frequency. The control of LH $\beta$ gene transcription by the transcription factor Early Growth Response 1 (EGR1) led to the hypothesis that the underpinning of the pulsed-dose differential regulation of the LH $\beta$ and FSH $\beta$ genes was EGR1. However, GnRHinduced JNK1 and MEK1 kinase activities, while essential, do not control EGR1 gene expression in a pulsed manner [12]. Another transcription factor, CREB, can bind to cAMP response elements on the $\mathrm{FSH} \beta$ gene promoter, and could give rise to the differential pulse effect on gonadotropin gene expression. In concert with this, it has been demonstrated that high pulse frequency of GnRH does give rise to elevated ICER, which would bind to CRE on the FSH $\beta$ gene and dampen its transcription [13]. Thusly, the induction of a negative regulatory transcription factor could potentially provide a mechanism for the differential regulation of gonadotropin gene expression under low and high pulse frequency.

Although a mechanism for differential gonadotropin gene expression, which can posit transcriptional factor dampening of transcription is compelling, it also suggests that adenylate cyclase is not the only downstream effector of GnRH. In this regard, it has been shown quite elegantly that the prostaglandin biosynthetic pathway, and in particular PGF $2 \alpha$ and PGI, can regulate not only LH $\beta$ and FSH $\beta$ gene transcription, but also the levels of GnRH receptor [14]. Such findings could have translational value for the adjuvant treatment of reproductive disease caused by gonadotropin imbalance and requiring differential pharmacologic intervention.

Since 1976 evidence has been provided, which showed the presence of the $\alpha$ subunit protein in non-pituitary and non-placental tissues [15]. Adding to the list, it was recently shown that HEK293 cells express high levels of $\alpha$ subunit mRNA (500 fold) and protein (600 fold) in response to elevation of cAMP caused by activation of transfected $\beta$ adrenergic receptor [16]. However, not only cAMP is involved because $\mathrm{G}_{\mathrm{q}}$-coupled receptor also induced expression of the $\alpha$ subunit. From these observations it is reasonable to suggest that the expression of the $\alpha$ subunit is not cell type dependent and the promoter likely embodies cyclic AMP response element (CRE) binding sites for CRE binding protein transcription factors. In addition, the control of this promoter can also be anticipated to respond to transcription factors that are regulated by intracellular levels of calcium.

Of course, every reproductive physiologist knows that castration gives rise to elevated gonadotropins in blood. Indeed, as ovarian function wanes in mid-life, and gonadal steroid production is decreased, FSH rises. Therefore, the long loop feedback of gonadal steroids on gonadotropin production was a harbinger of the potential for regulation of gonadotropin gene expression by gonadal steroids. However, the regulation of gonadotropin secretion by progesterone was unanticipated. Progesterone increases FSH $\beta$ gene expression but GnRH-induced LH $\beta$ gene expression is repressed [17, 18]. Moreover, whereas induction of FSH gene expression is due to progesterone receptor binding to the promoter of the FSH $\beta$ gene, in the case of $\mathrm{LH} \beta$ gene regulation, progesterone receptor is not required [18]. Gonadal steroids also modulate neuronal firing and, therefore, secretion of gonadotropins. For example, during the estrous cycle, progesterone increases the locus coeruleus expression of fos related proteins and firing whereas in high estrogen expression is lower and lowered fos related antigen staining [19].

We would be remiss to not mention here that steroidal control of gonadotropin secretion can also be mediated by hypothalamic kisspeptin neurons controlling the release of $\mathrm{GnRH}$ [20]. Along these lines, it is also important to mention the hypothalamic factor, Gonadotropin Inhibitory Hormone (GnIH or RFRP-1,-2,-3 peptides), which inhibits release of gonadotropins mediated by GnRH [21]. Both types of neurons are emerging as positive and negative mediators of gonadal feedback, respectively, as well as environmental regulators of GnRH neurons [22]. The GnIH peptides, originally identified in avian species, have been found in mammalian species in recent years, and studies are in progress to confirm $\mathrm{GnIH}$ plays similar roles in mammalian reproduction [21]. Co-localization studies have shown $40-80 \%$ of GnRH neurons close to GnIH-positive fibers, implying a direct effect on GnRH secretion. Animal studies in rat, sheep, and cattle supported direct effects of $\mathrm{GnIH}$ on gonadotropes, however, a negative result in rats suggested species-specific differences in the mechanism of action for these peptides. A G protein-coupled receptor, GPCR147, for GnIH has recently been detected in human hypothalamic neurons and pituitary gonadotropes, suggesting clinical significance for GnRI peptides as adjuncts or alternatives to $\mathrm{GnRH}$ analogs [23].

During the 1970s a search for non-steroidal factors that regulate gonadotropin release led to the identification of 
inhibin, which suppresses FSH secretion, and then serendipitously activin, which increases FSH secretion. Both inhibin and activin are members of the TGF $\beta$ superfamily which appear to preferentially control the secretion of FSH [6]. Activin acts as an autocrine/paracrine factor in the anterior pituitary, and stimulates FSH $\beta$ gene transcription, whereas inhibin, acting as an ovarian hormone, is inhibitory [24]. Interestingly, another TGF $\beta$ family member, bone morphogenetic protein-4, while having no effect on its own, can modify activin- as well as GnRH-mediated gonadotropin release by increasing mRNA of FSH $\beta$ [25].

Regulation of chorionic gonadotropin expression is less well understood in part because no obvious placental signal has been identified. Chorionic gonadotropins have been found in only two groups of mammals, primates and equids. When only human and horse chorionic gonadotropins were well characterized, chorionic gonadotropin expression was apparently exclusively placental in humans, as a separate pituitary LH existed, whereas in the horse, pituitary LH and placental CG were found to be comprised of identical polypeptides. In the human, the $\mathrm{CG} \beta$ gene appeared to be derived from an ancestral LH $\beta$ gene, which was located on the same chromosome and in the same gene cluster. In the horse it was not known if a similar gene duplication was followed by loss of one gene, as donkeys and zebras also appear to possess only a LH/CG $\beta$-like gene. Recent studies of new world monkey CG may provide an example of a path from separate LH and CG $\beta$-subunit genes to a single $\mathrm{LH} / \mathrm{CG} \beta$ gene. The common marmoset (Callithrix jacchus) was found to possess both LH and CG $\beta$-subunit genes, however, only the $C G \beta$ gene was expressed in the pituitary [26]. As the structural gene appeared normal, the absence of expression probably reflects changes in regulatory elements. Two other new world monkeys, the squirrel monkey (Saimiri sciureus) and the owl monkey (Aotus trivirgatus) were also reported to express only the $\mathrm{CG} \beta$ gene in the pituitary [27]. The potential for pituitary expression of $C G \beta$ exists even in humans, as the presence of pituitary-derived hCG was confirmed by its possession of pituitary-specific sulfated glycans [28]. The mechanisms for loss of pituitary expression of LH $\beta$ may emerge from studies of new world monkeys.

\section{Regulation of gonadotropin assembly and secretion}

It is clear that initiation of events that lead to gonadotropin gene expression rests at the level of secretagogues, and is modulated by several factors. The biosynthesis of the gonadotropin subunits can be considered in three steps. Translation involving the cytoplasm and the endoplasmic reticulum (ER), glycosylation and assembly taking place in the ER, glycan remodeling, hormone packaging and secretion taking place in the Golgi and secretogranins. Both subunits are glycosylated, and the timing of glycosylation relative to translation and transfer to the ER, as well as protein folding and assembly is still unclear. Only very early work is available on this topic. Rat LH subunits were reported to associate early in the secretory pathway based on endoglycosidase $\mathrm{H}$ sensitivity [29]. Ruddon's lab reported assembly of hCG subunits into heterodimer preparations possessing glycans $\left(\mathrm{Gn}_{2} \mathrm{M}_{9} \mathrm{Glc}_{1}\right.$ or $\mathrm{Gn}_{2} \mathrm{M}_{8}$ consistent with ER residency [30], as did Magner and Weintraub for TSH [31].

Since the glycoprotein hormones are heterodimeric, it could be anticipated that the expression patterns for both genes that encode the $\alpha$ and $\beta$ subunits are coordinated, lest the production of either subunit be in vain without a partner to form the heterodimer. Alternatively, excess of one hormone can drive dimer formation. An early study showed that in placenta the ratio of $\mathrm{hCG} \alpha: \mathrm{hCG} \beta$ synthesis is $1.7: 1$ in early pregnancy and 12:1 at term [32]. In the pituitary, this is difficult to evaluate because the $\alpha$ subunit synthesis is associated with three $\beta$-subunits for FSH, LH and TSH. Moreover, while hCG $\beta$ is often secreted as $\alpha$ free subunit, $\mathrm{LH} \beta, \mathrm{FSH} \beta$, and TSH $\beta$ are largely degraded intracellularly, presumably because of improper folding. Failure to associate with the $\beta$ subunit results in aberrant glycosylation of the $\alpha$ subunit. In the pituitary, the major difference is the Oglycosylation of $\mathrm{Thr}^{39}$, while in the placenta, increased Nglycan branching replaces predominantly hybrid and biantennary glycans with predominantly tri- and tetra-antennary glycans. Unlike studies which examine gene expression, using mRNA or promoter activation as readouts, an understanding of the structural and cell biology of gonadotropin secretion has relied upon readouts of secretion rates using pulse-chase analysis and formation of competent hormones often interpreted in light of mutational analysis.

Crystal structures of the gonadotropins and the FSH receptor provide a physical reference for such interpretations [33]. Figure 2 shows that the $\alpha$ and $\beta$ subunits each with three loops, orient in a head to tail 2-1/1-2 manner and that the $\beta$ subunit carboxy-terminal tail is wrapped around the $\alpha$ subunit [34]. A terminal cysteine residue forms a disulfide bond with the $\beta-1$ loop providing a latch for the so-called "seat belt". A nuance of the seat belt is that a portion of it is gathered into a small cystine noose, whose importance will become clear later in this paper. Although glycoprotein $\alpha$ and $\beta$ subunits can assemble in vitro, the process is slow but can be accelerated by removal of the carbohydrate in the second loop of the $\alpha$ subunit. This observation squared with observations using pulse chase studies, and so it was surmised that in vitro the association of subunits relied on them to find a way for glycosylated loop 2 of the $\alpha$ subunit to slide under the seat belt (no small feat with carbohydrate attached), while in vivo, it was possible that formation of the seatbelt clasp occurred 
Fig. 2 Three-dimensional structures for $\mathrm{hCG}$ and $\mathrm{hFSH}$. The structures were derived from protein databank files 1HRB and 1FL7, respectively, [106] and the $\alpha$-carbon backbones visualized using the software package iMol (http://www.pirx.com/iMol/). Diagrams were exported from $\mathrm{iMol}$ as encapsulated postscript files and structural elements labeled using the software package Adobe Illustrator. The subunits are associated in an anti-parallel manner with three Cys-knot loops at opposite ends: $\beta$ L1$\beta \mathrm{L} 3-\alpha \mathrm{L} 2$ at one end and $\alpha \mathrm{L} 1-$ $\alpha \mathrm{L} 3-\beta \mathrm{L} 2$ at the other. The receptor-binding elements are located on the right side of each model and consist of $\alpha \mathrm{L} 2, \beta \mathrm{L} 2$, the $\alpha$-subunit $\mathrm{C}$-terminus, along with the seatbelt loop of which, the Cys-noose, featured in the subunit threading mechanism, is most readily visible

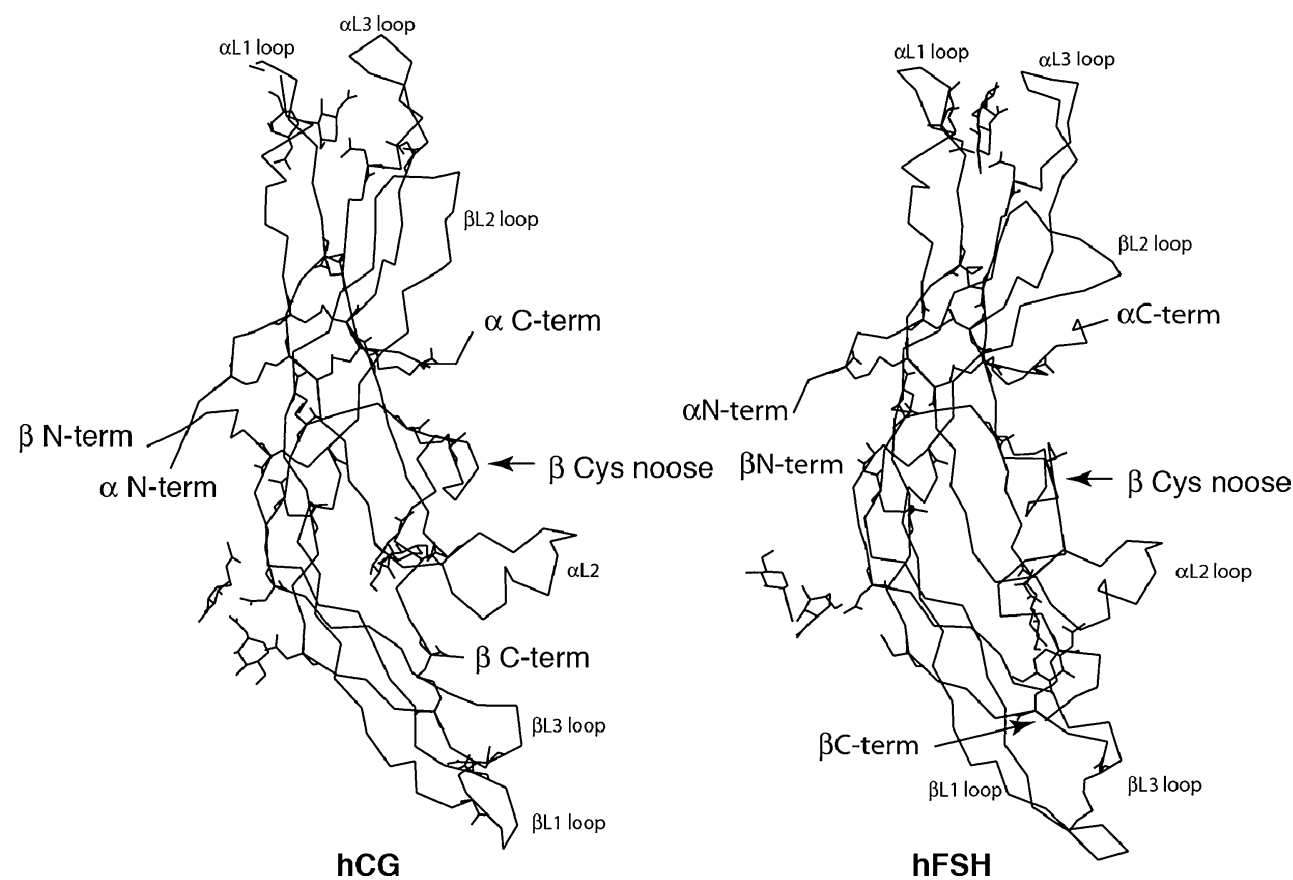

following protein folding and assembly of the subunits into the heterodimer.

The reasonable notion that in vivo seatbelt latching occurred following subunit association remained largely untested for 8 years after the crystal structure of hCG [35, 36] was published (Fig. 3). But shortly after the crystal structure of FSH [37] was published, confirming the seat belt motif as a general principle for the gonadotropins, subsequent studies were performed using mutagenesis and antibody binding which suggested that threading of the $\alpha$ subunit through the closed seat belt is the predominant pathway for assembly [38]. The conundrum of how this can occur was partially solved by a subsequent observation involving the cystine noose referred to above. It turns out that removal of the disulfide bond of this noose facilitates assembly of the subunits into the heterodimer, in effect letting out the gather of the seatbelt [39]. This mechanism would necessarily be underpinned by a redox-coupled system, but what this system is and whether it is regulated is not clear at this time. The compact nature of the GlcNAc $_{2} \mathrm{Man}_{9} \mathrm{Glc}_{1}$ glycan may also facilitate threading as, in vitro subunit association is most commonly studied using hCG and various mammalian LH $\alpha$ subunits possessing smaller, hybrid-type glycans (Fig. 4) attached to the $\alpha$ L2 Asn (residue 52 in humans, 56 in most mammals). In contrast, triantennary glycans, such as those attached to placental free $\alpha$ subunit [40], prevent subunit association, while elimination of this glycan facilitates subunit association $[41,42]$. In fish, the mechanism of assembly appears to follow the less efficient pathway where the subunits assemble first and then the seat belt wraps around the $\alpha$ subunit and is latched [43]. The current thinking on this pathway to assembly of the receptor binding competent heterodimer is as follows: Parts of the $\beta$ subunit amino terminus, reduced cystine knot, and $\alpha$ subunit loops 1 and 3 dock; then the $\beta$ subunit amino terminus and the oxidized cystine knot (gathered again into a noose) in complex with $\alpha$ subunit loop 2, form the stable heterodimer [44]. The reader is referred to these elegant and rather detailed studies for further information.

The secretion of the gonadotropic hormones has been studied by pulse chase methods, followed by immunoprecipitation of the heterodimeric hormone and analysis of the labeled subunits by gel electrophoresis. One of the first differences in secretion noted, actually came from a comparison of hCG and hLH, which are identical except for a $\beta$ subunit carboxyterminal extension that is O-glycosylated in hCG and is absent in hLH. Using a cell line that exhibits apical/basal secretion, it was shown that hCG was secreted apically whereas LH was secreted basally [45, 46]. It has since been determined that the apical secretion of $\mathrm{hCG}$ is constitutive when compared to heterodimeric $\mathrm{LH}$ and that the carboxy terminal tail of hCG $\beta$, which is not present in $\mathrm{hLH} \beta$, is necessary for the constitutive apical secretion [47]. When compared to $\mathrm{LH}, \mathrm{FSH}$ was found to sort into both apical and basolateral secretory compartments, and in $\mathrm{LH}$, the signal for basolateral secretion was found in the last seven amino acids of the $\beta$ subunit [48]. The secretion of $\mathrm{hFSH}$ is constitutive, whereas LH secretion is induced by 


\section{A. Ruddon tethering model for subunit association}

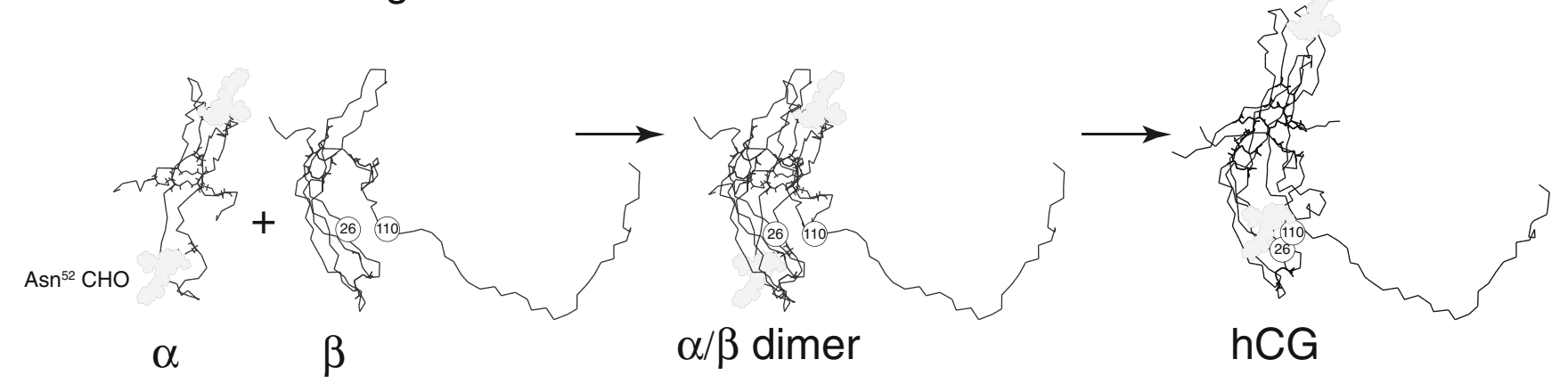

\section{B. Moyle threading model for subunit association}

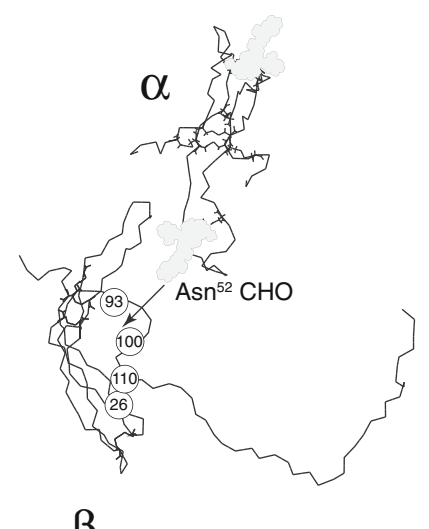

$\beta$

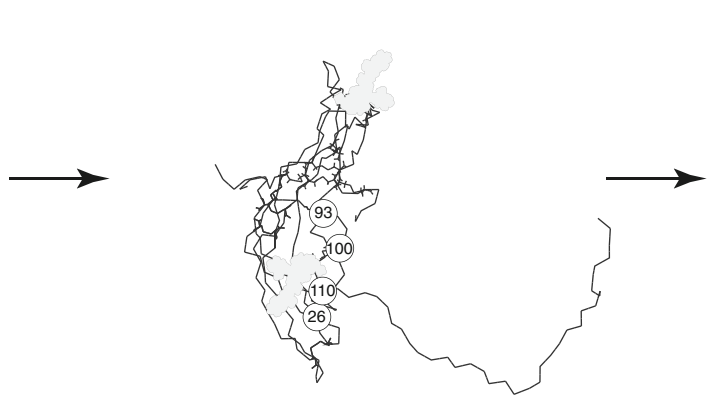

$\alpha / \beta$ dimer

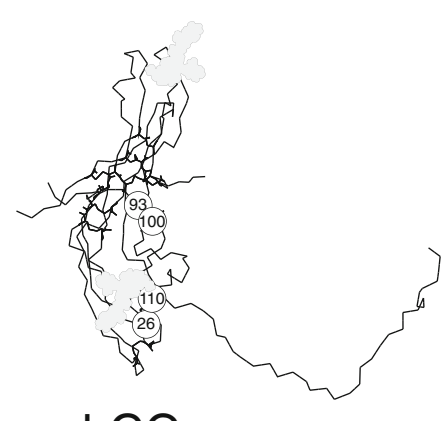

hCG
Fig. 3 Mechanisms for hCG subunit association. A. Classic tethering mechanism proposed by Ruddon and colleagues [107]. The $\alpha$ subunit is folded and ready for association. Partially folded hCG $\beta$ gains dimerization competency when the 93-100 disulfide bond forms. Subunits dock, forming inactive $\alpha / \beta$ dimer. Active conformation forms and formation of 26-110 disulfide stabilizes functional hCG. B. Alternative threading mechanism proposed by Moyle and colleagues

stimulation, and this difference is due to the hydrophobic stretch of amino acids (LSGLLFL) in the LH $\beta$-subunit tail [49]. In fact, FSH secretion could be switched from constitutive to regulated by fusing that sequence to the carboxyl terminal $\beta$-subunit tail of FSH $[49,50]$.

With regard to LH secretion, lipid rafts were recently implicated in the mechanism for LH secretion when drugs known to disrupt lipid rafts were shown to stimulate $\mathrm{LH}$ secretion in vitro and in vivo [51]. The mechanism involved appears to be controversial, as SNARES, reportedly associated with rafts, are released, and in other systems either stimulate or inhibit protein secretion.

\section{Terminal glycosyl modification and therapeutic gonadotropin preparations}

One of the striking differences between FSH and LH, apart from their $\beta$ subunits, is that the majority of carbohydrates on
$[38,39,43,44]$. The hCG $\beta$ 26-100 seatbelt loop disulfide bond has formed, and the 93-100 disulfide opens, thereby enlarging the seatbelt loop. The $\alpha$ subunit with a compact glycan threads through the enlarged seatbelt loop, forming inactive $\alpha / \beta$ dimer. Active $h C G$ conformation in $\alpha \mathrm{L} 2$ is established and 93-100 disulfide bond reforms. To simplify the diagrams, only the $\alpha$ subunit $\mathrm{N}$-glycans are indicated as outlines of the GlcNAc${ }_{2} \mathrm{Man}_{9} \mathrm{Glc}_{1}$ oligosaccharide

FSH are terminated with sialic acid whereas the vast majority carbohydrates on LH are terminated in sulfate. In this regard, $\mathrm{hLH}$ glycosylation is an exception, as $28 \%$ of the glycans are terminated with sialic acid (Fig. 5) [52]. In the original model for glycoprotein clearance, sialic acid prevented recognition of the terminal galactose residues by Ashwell's lectin, the asialo-glycoprotein receptor (ASGP-R) [53], thus prolonging hFSH half-life in the blood. However, this was consistent only with $\alpha 2-3$ linked sialic acid residues found in hCG, which was used in the pioneering Ashwell experiments [54]. Interestingly, the ASGP-R did not appear to be involved in clearance of sialylated hCG, as saturating the receptor with desialylated glycoproteins had no effect on native hCG clearance, while slowing asialohCG clearance [55]. Subsequently, Baenziger and colleagues demonstrated that $\alpha 2-6$ linked sialic acid did not prevent galactose residue recognition by the ASGP-R (Fig. 6), which is relevant for hFSH and hLH, as they possesses both $\alpha 2-3$ and $\alpha 2-6$ linked sialic acid residues 
Fig. 4 Models of N-glycans found attached to $\alpha$ Loop2 $\mathrm{Asn}^{52}$ (human numbering). A. Top view of glycans found on $\mathrm{hCG} \alpha$ under various conditions. B. Side view of the same glycans. The $\beta(1-4)$-linked Man residue that initiates branching is labeled in both views of each structure. C. Diagrams of glycan structures showing monosaccharide residues and linkages for glycans in A and B. Oligosaccharide models were built with the Woods Group (2005-2011) Glycam Web Carbohydrate Builder. Complex Carbohydrate Research Center, University of Georgia, Athens, GA. (http:// www.glycam.com) Structure 1, high mannose glycan $\mathrm{GlcNAc}_{2-}$ $\mathrm{Man}_{9} \mathrm{Glc}_{1}$ found in ER on folding proteins; structure 2, typical urinary hCG-derived, hCG $\alpha$ $\mathrm{Asn}^{52}$ hybrid-type N-glycan; structure 3, triantennary glycan, such as those associated with urinary free $\mathrm{hCG} \alpha$

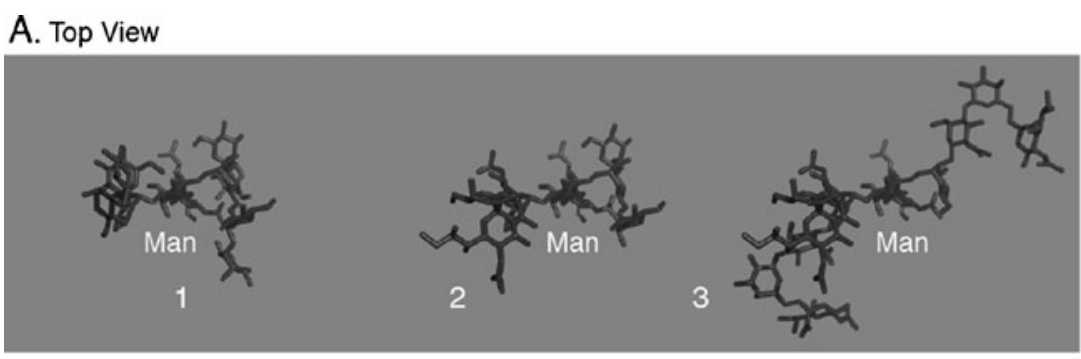

B. Side View

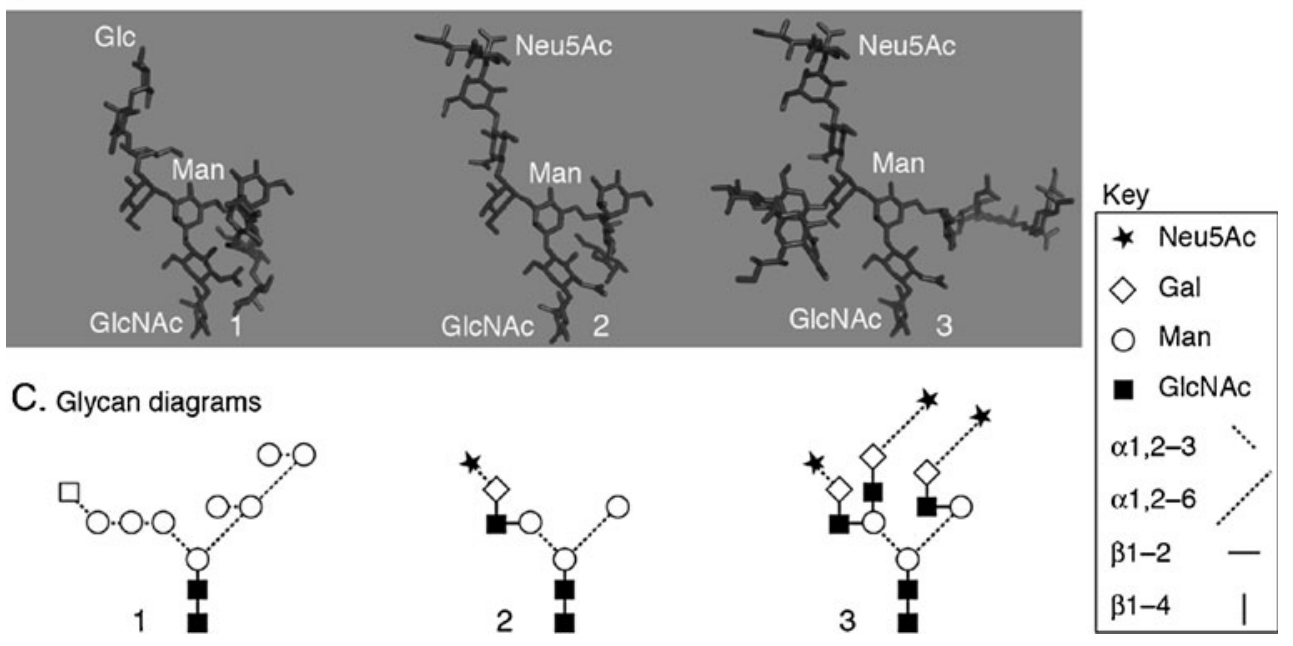

[56]. Moreover, in the female rat pituitary, estrogen feedback has been shown to regulate the expression of $\alpha 2-3$-sialyltransferase (ST3Gal III) [57]. In contrast, in the male $\alpha 2-6$-sialyltransferase (ST6Gal I) appears to be under

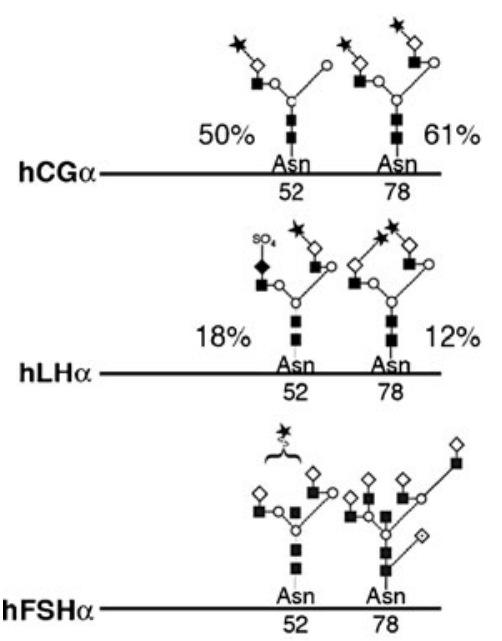

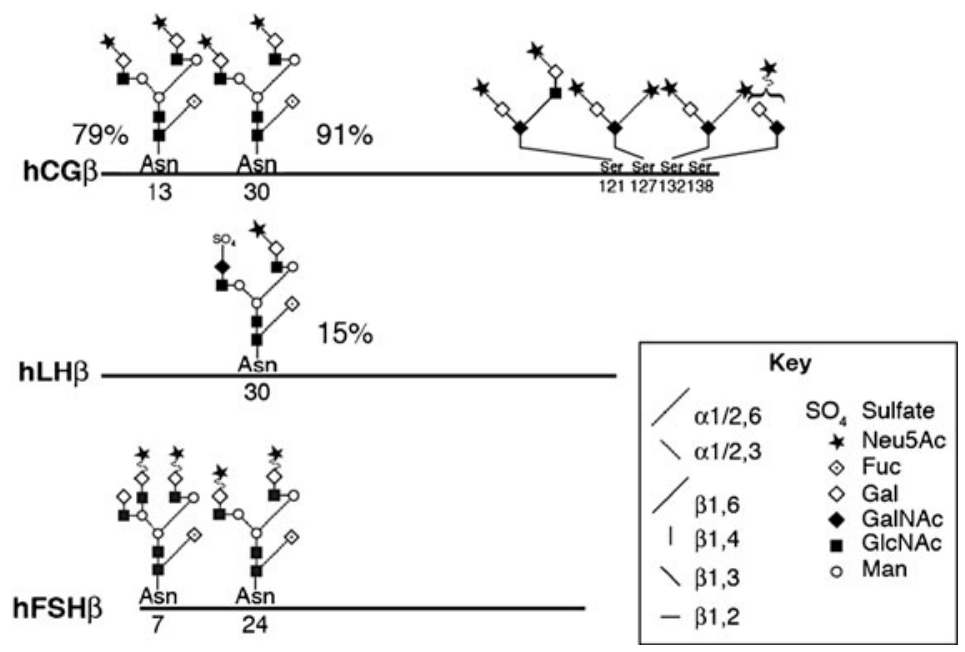

$10 \%$ or fewer $\alpha$-glycans. The $\beta$-subunit glycans are shown with core fucose, as $80-90 \%$ of $\beta$-glycans possess this residue. The O-glycan distribution is as determined by mass spectrometry of tryptic glycopeptides [97]. Glycan diagrams follow the Oxford Glycobiology Institute format [109] except that 1-6 and 2-6 bonds are indicated by a longer line to emphasize that the monosaccharide is attached to a potentially more flexible linkage via an exocyclic carbon atom, rather than to a ring carbon (see Key inset). Note that sialic acid is attached only via $\alpha 2-3$ linkages in hCG, but both $\alpha 2-3$ and $\alpha 2-6$ linkages are found in $\mathrm{hLH}$ and $\mathrm{hFSH}$ (although not shown for hFSH glycopeptides, it is well known from studies involving oligosaccharides) 


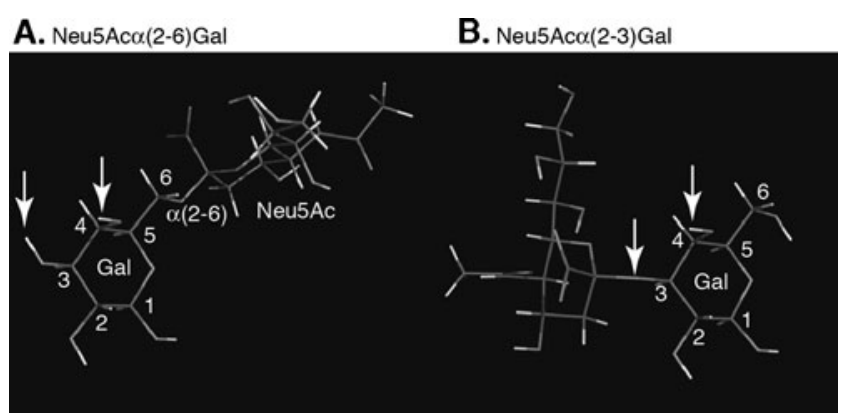

Fig. 6 Asialoglycoprotein ligands. Based on similarities between the mannose binding protein and ASGPR carbohydrate binding domains, the latter is expected to bind hydroxyls attached to Gal carbons 3 and 4 (arrow, see p 184 [110]). A. The $\alpha 2-6$-linked sialic acid does not block access to these. B. The $\alpha 2-3$-linked sialic acid blocks access to both hydroxyls by replacing the C-3 hydroxyl with a glycosidic bond and potentially steric hindrance of the C-4 hydroxyl

gonadal regulation, but not $\alpha 2-3$-sialyltransferase [58]. If gonadotrope expression of these enzymes is regulated by estrogen, then one potential mechanism for increasing the clearance rate of FSH may involve increasing the relative abundance of $\alpha 2-6$-linked sialic acid terminating FSH glycans as compared with $\alpha 2-3$-linked sialic acid. The sulfate on the other hand decreases the half life of LH providing for more fine control of blood levels in most species [59]. Although it seemed reasonable to hypothesize that the sulfation of terminal carbohydrate may in some way direct LH to the inducible secretory pathway, inhibition of sulfation did not shunt LH to the constitutive pathway [60]. One problem with this hypothesis is the fact that FSH from nonhuman mammals is decorated with $13-40 \%$ sulfated glycans $[56,61,62]$. Thus, human FSH represents a special case in that sulfated glycans represent less than $10 \%$ of the total glycan population [56, 62]. Moreover, hLH possesses 22 $39 \%$ sialylated glycans at each glycosylation site, with sialic acid linked both $\alpha 2-3$ and $\alpha 2-6$. Human LH clearance more closely resembles that of hFSH than $\mathrm{LH}$ from other mammalian species because it ends up in the urine while more highly sulfated LH preparations, such as $\mathrm{pLH}$, do not [63].

Pharmaceutical-grade recombinant human gonadotropins are expressed in Chinese hamster ovarian cells (Table 1), and their glycosylation reflects glycosyl transferase expression in that cell line. MALDI-TOF-MS and ESI-MS, as well as MS/MS analysis of glycans derived from recombinant $\mathrm{hLH}, \mathrm{hFSH}$, and hCG preparations produced by EMD Serono, revealed only sialylated glycans associated with these gonadotropin preparations [64]. The most abundant glycans were biantennary, although lesser amounts of tri-, tetra-, and even penta-antennary glycans were also detected. For hCG and hLH, the natural forms of these hormones are largely decorated with biantennary glycans. For hLH, the absence of sulfate and $\alpha 2-6$-linked sialic acid [65] would appear to eliminate both liver clearance mechanisms, thereby prolonging $\mathrm{hLH}$ survival in the serum. Longer halflife would not seem to affect clinical use of hLH, as hCG, with an even longer halflife, is typically substituted for hLH to induce ovulation. Moreover, one clearance study in primates indicated only a modest reduction in recombinant hLH clearance as compared with pituitary hLH [66]. This result is consistent with an in vivo imaging analysis of the clearance of $\mathrm{pLH}$, a highly sulfated gonadotropin preparation, in rats [63]. The labeled hormone was only transiently associated with the liver during the distribution phase, and clearance appeared to take place largely in the kidneys. For recombinant $\mathrm{hFSH}$, the abundance of triantennary and tetraantennary glycans appears to be higher than observed in recombinant $\mathrm{hLH}$ and hCG preparations, but lower than in pituitary hFSH [64]. The distribution of glycans on the FSH molecule may be important for biological activity. Glycopeptide mass spectrometry, which potentially could simultaneously characterize all four FSH glycosylation sites, provided detailed information only for two sites, $\alpha \operatorname{Asn}^{52}$ and $\beta \operatorname{Asn}^{7}[62,67]$. Limited data hinting at preferential attachment of highly branched glycans at $\alpha \mathrm{Asn}^{78}$ need confirmation [67].

The focus on FSH isoforms for the last 38 years has emphasized terminal charged residues on the associated glycans because sulfate and sialic acid residues are negatively charged and the existence of charge heterogeneity is attributed to these residues. However, FSH glycosylation variations also include the absence of one or both $\mathrm{N}$ glycans and branching of the glycans, as well as terminal sialylation or, to a lesser extent, sulfation. Thus, $90 \%$ of horse (e)FSH $\beta$ lacks $\mathrm{Asn}^{7}$ glycans, while $13-54 \%$ of pituitary $\mathrm{hFSH}$ preparations lack both $\mathrm{hFSH} \beta$ glycans [68]. The latter pattern may also exist in two other primate species, Rhesus macaque (Macaca mulatta) and Japanese
Table 1 Recombinant gonadotropin preparations

${ }^{a}$ Formerly Serono
${ }^{b}$ Formerly Organon

\begin{tabular}{llll}
\hline Hormone & Trade Name & Manufacturer & Cell Line \\
\hline FSH & ${\text { Gonal- } \mathrm{f}^{\circledR}}^{\circledR}$ & EMD Serono $^{\mathrm{a}}$ & Chinese Hamster Ovary (CHO) cells \\
FSH & Follistim $^{\circledR}$ & Merck $^{\mathrm{b}}$ & CHO cells \\
LH & Luveris $^{\circledR}$ & EMD Serono & CHO cells \\
CG & Ovidrel $^{\circledR}$ & EMD Serono & CHO cells \\
\hline
\end{tabular}


macacque ( $M$. fuscata). While LH glycans are typically, hybrid or complex, biantennary [52], FSH largely lacks hybrid glycans, and possesses complex: biantennary, triaantennary, and tetraantennary glycans [56, 62, 69]. In $\mathrm{hFSH}$, triantennary and tetraantennary glycans amplify heterogeneity as mono-, di-, and tri-sialyl variants of triantennary and tetraantennary glycans are found [62]. Terminal sialylation has been assumed to produce FSH isoforms, however, mass spectrometry of isoform glycans revealed a great deal of similarity in the glycan populations of FSH isoforms [67]. While two studies have examined expression of two sialyl transferases [57, 58], understanding sialylation is complicated by the large number of sialyltransferase isoforms that exist in mammals. For example, there are 20 sialyltransferase genes in the mouse and human genomes [70]. These are arranged into four classes based on sialic acid linkage to the underlying glycan and substrate specificity [71]. The $\alpha 2,6$-sialyltransferases ST6Gal I-II and the $\alpha 2,3$-sialyltransferases ST3Gal III, IV, and VI are capable of attaching sialic acid to terminal Gal or GalNAc residues in gonadotropin $\mathrm{N}$-glycans. While pituitary gonadotropins possess both $\alpha 2,3-$ and $\alpha 2,6$-linked sialic acid, placental hCG and recombinant gonadotropins produced in Chinese hamster ovarian cells possess only $\alpha 2,3$-linked sialic acid. Recent developments in mass spectrometry procedures should facilitate identification of sialyltransferases involved gonadotropin synthesis. Modification of sialylated glycans with 4-(4,6-dimethoxy-1,3,5-triazin-2yl)-4-methylmorpholinium chloride not only stabilizes sialylated glycans for analysis, but also distinguishes $\alpha 2,3$ from $\alpha 2,6$ linked sialic acid [72]. The relatively modest amounts of hormone needed, $10 \mu \mathrm{g}$, makes it feasible to evaluate the effects of modifying sialyltransferase expression on gonadotropin glycosylation. However, future Istudies should also examine oligosaccharyltransferase, which initiates N-glycosylation, and the GlcNAc transferases responsible for complex glycan branching.

\section{Regulation of N-glycosylation and branching}

$\mathrm{N}$-glycosylation is initiated by an 8-subunit enzyme complex called oligosaccharyl transferase (OST) that transfers a preformed precursor oligosaccharide from dolichol pyrophosphate to the nascent glycoprotein chain $[73,74]$. Partially Nglycosylated forms of recombinant hCG and pituitary FSH have been reported, while LH and TSH appear to be completely glycosylated, as is the common $\alpha$ subunit. The all-or-none N-glycosylation of $\mathrm{hFSH} \beta$, appears to be the result of selective inhibition of OST activity, as the complementary $\mathrm{hFSH} \alpha$ subunit is quantitatively glycosylated [75]. In yeast there are 9 genes for 8 OST subunits [76]. Mammalian equivalents of the yeast subunit genes have been identified [74] as well as two isoforms of the catalytic subunit, STT3 [77]. Immunopurified yeast OST appears to be a dimer based on blue gel electrophoresis in which the major band was estimated to be a $500 \mathrm{kDa}$ complex, while protein sequences predicted a $250 \mathrm{kDa}$ molecular weight [78]. The yeast enzyme appears to be regulated by PKC [79], which is interesting because PKC is the primary signaling pathway activated by GnRH. The challenge is to understand how glycosylation of the FSH $\beta$ subunit is selectively inhibited, while permitting full glycosylation of the common $\alpha$ subunit, not to mention the $\mathrm{LH} \beta$ subunit, within the same cellular compartment. One possible mechanism could involve the use of different OST isoforms.

Some lessons have been learned from studies in yeast. Two OST isoforms have been identified in yeast that differ in one subunit, Ost3p or Ost6p [80]. Mammalian homologs for both subunits are, N33 and IAP, respectively [81]. Mammalian OST isoforms also differ in the nature of the putative catalytic subunit STT3 [81]. STT3A appears to be involved in cotranslational N-glycosylation, while STT3B appears to be involved in post-translational N-glycosylation [77]. Possible posttranslational glycosylation of FSH subunits might occur, as a low MW form was detected during pulse-chase expression of $\mathrm{hFSH}$, that chased into the high MW form over time [82]. Thus, it may be possible to inhibit $\mathrm{FSH} \beta$ glycosylation by knocking down STTB expression. Each of the yeast OST isoforms is associated with a specific translocon; OST possessing Ost3p with Sec61 and OST possessing Ost6p with Ssh1p [80]. Yeast translocons differ in the specificity of the signal peptides that they accept. Sec61 is necessary for cell viability and accepts a wider range of signal peptides while Ssh1p is less essential and accepts signal peptides with high hydrophobic character. Analysis of signal peptides for the common $\alpha$ subunit and hFSH $\beta$ with the DNA Star Protean software revealed a hydrophilic Nterminus in the first 8 residues of the common $\alpha$ subunit signal peptide and a hydrophobic N-terminus in the first 9 residues of the FSH $\beta$ signal peptide. This suggests a strategy of swapping leader sequences between the $\alpha$ and FSH $\beta$ subunits, however, a mammalian homolog of Sshlp does not appear to exist. An uncharacterized homolog of Sec61 (accession number D3ZEH3) does exist in the rat that is the same size and is $93 \%$ identical to Sec61. In principle, mass spectrometry should permit analysis of partially glycosylated FSH variants, however, oligosaccharide heterogeneity, particularly that associated with the common $\alpha$ subunit obscures $\mathrm{FSH} \beta$ isoforms lacking one or more $\mathrm{N}$-glycans [68].

$\mathrm{N}$-glycosylation in the ER is a highly conserved process with defined intermediates involved in protein folding, exit of folded protein to the Golgi, and the retrograde transport of unfolded proteins to the cytoplasm for proteosomemediated degradation [83]. Glycan diversity is subsequently generated in the Golgi, and glycan branching is a major 
contributor. Branching is regulated by a family of GlcNAc transferases, which are characterized by the core mannosyl residue and linkage of the GlcNAc residue attached to the pentasaccharide core. All but the bisecting GlcNAc residue, which is attached $\beta(1-4)$ to the $\beta(1-4)$-linked Man residue, can be extended by other glycosyltransferases to yield the mature branches of the glycan. Based on the existence of largely hybrid and biantennary glycans attached to hCG and $\mathrm{hLH}$, along with triantennary and tetraantennary glycans attached to hFSH, the following GlcNAc transferases modify gonadotropin glycans: MGAT1 (GlcNAc transferase I), MGAT2 (GlcNAc transferase II), MGAT3, (GlcNAc transferase III), MGAT4 (GlcNAc transferase IV), and MGAT5 (GlcNAc transferase V). LH and hCG glycans are products of GlcNAc transferase I alone, or both I and II, as only hybrid or biantennary glycans decorate these hormones. In the mouse and human genomes there are single genes for GlcNAc transferases I, II, and III, while there are 2 isoforms for both GlcNAc transferases IV and V. Loss of GlcNAc transferase I in the whole mouse is embryonic lethal [84] and oocyte-specific knock out leads to a reduced ovulation rate [85]. Loss of GlcNAc transferase II in mice is often embryonic lethal, but can be studied in some genetic backgrounds, which provide a model for the human disease congenital disorder of glycosylation type IIa [86]. Male mice with this disorder are sterile due to spermatogenic failure, while humans exhibit testicular atrophy. Loss of GlcNAc transferase III appears to inhibit growth factor signaling [87] and can counteract the metastatic properties of tumor cells expressing GlcNAc transferase V [88]. Both GlcNAc transferases IV and V are responsible for tri- and tetra-antennary glycan synthesis. These glycans appear to interact with galectins to prolong surface residence of membrane glycoproteins, which may be relevant to FSH, as recently galectin1 was detected in porcine granulosa cells. Moreover, galectin-1 inhibited FSH-stimulated steroidogenesis in these cells [89]. GlcNAc transferase IV exists as two isoforms IVa and IVb. The former is normally expressed in the digestive system, while the latter is more broadly expressed. However, when the IVb gene was knocked out, compensatory expression of the IVa gene appeared to largely make up for the loss of the former [90]. Mice deficient in MGAT5A were reported in 2002, and exhibited susceptibility to autoimmune disease, reduced cancer progression, and a behavioral defect [91]. A year later the existence of a second isoform, MGAT5B was reported [92]. Expression of the former is widespread, while the latter is restricted to neural tissue and the testis. Thus, the full ramifications of this transferase have not yet been examined. Because contemporary mass spectrometry techniques can analyze glycans derived from as little as $10 \mu \mathrm{g}$ recombinant gonadotropin, it is feasible to monitor the results of modifying GlcNAc transferase activities on the glycan populations associated with these hormones.
Hyperglycosylated hCG is one of several variants of this clinically and diagnostically valuable gonadotropin, and is associated with early pregnancy and cancer $[4,93]$. Early pregnancy hyperglycosylated hCG is secreted by extravilous cytotrophoblast cells, and not by the syncytiotrophoblast [94]. It appears to act in an autocrine/paracrine manner to promote cytotrophoblast invasion of the uterus [95]. Typically, hyperglycosylated hCG is identified in clinical studies by the binding of monoclonal antibody B152 that is dependent on the presence of a core type-2 O-glycan at Ser132 instead of the usual disialylated core type-1 glycan (Fig. 5, illustrates these glycan structures at positions 121 and 132, respectively, for normal pregnancy hCG). Reduced hyperglycosylated hCG is associated with increased risk for early pregnancy loss [96]. Glycosylation site-specific differences in glycan structure between tumor-derived hyperglycosylated $\mathrm{hCG}$ and normal pregnancy $\mathrm{hCG} \beta$ subunits have been defined by mass spectrometry [97]. A site-specific increase in the abundance of tri-antennary glycans over bi-antennary glycans was observed at $\beta \mathrm{Asn}^{30}$, but not $\beta \mathrm{Asn}^{13}$. As $\mathrm{Asn}^{30}$ glycans are involved in signal transduction, this may have functional significance, since hyperglycosylated hCG has been shown to be impaired in its steroidogenic potency, yet promotes cell invasion by cytotrophoblasts [95]. On the other hand, the increased abundance of fucosylated glycans at $\mathrm{Asn}^{13}$, may also influence function, as lentil lectin-bound TSH was reported to exhibit biased agonism, activating both cAMP and PLC pathways, while unbound TSH activated only the cAMP pathway [98]. Mass spectrometry also better defined the differences in O-glycosylation, revealing changes from core type 1 to core type 2 glycans at Ser132 and Ser138, as well as increased glycosylation site occupancy at Ser127 [97].

\section{Glycosylation and therapeutic function}

The design and implementation of glycoprotein hormones for therapeutic purposes in part relies on and is limited by their structural requirements for biosynthetic processes, in particular the regulation of glycosylation [99]. The heterogeneity of gonadotropin glycosylation has led to many theories about the relative role of differentially charged isoforms and concerns about their pharmacological properties [100-102]. Gonadotropin utility in humans and more recently in domestic animals [103] has encouraged thinking about strategies to enhance half-life and whether glycosylation plays roles in biological activity apart from circulatory halflife. Emerging strategies for homogenous glycosylation of the subunits could potentially allow for the preparation of completely homogenously glycosylated gonadotropins, which would be an improvement of the existing formulation [104]. Indeed the finding that glycosylation of the $\beta$ subunit of 
$\mathrm{hFSH}$ varies with age has prompted thinking that new forms of therapeutic gonadotropins should include more diglycosylated as in young women [68]. Thus cycling young women have a greater proportion of heterodimeric FSH, which is not glycosylated at all on the $\beta$ subunit, whereas menopausal women have a higher proportion of FSH which is glycosylated on all four sites [68]. It is reasonable to assume that there will be differences in biological activities of the tetra and di-glycosylated FSH because already there is evidence for biased agonism with other glycoform variants of hFSH [105].

\section{Future directions}

Current second generation gonadotropin preparations incorporate changes in the protein moieties to increase stability by expressing the $\alpha$ and $\beta$ subunits as single-chain molecules and to increase survival in the circulation by addition of the $\mathrm{hCG} \beta$ C-terminal peptide. The control of transcription of genes encoding proteins that are involved in the post-translational modifications of the gonadotropins, although more complicated, seems warranted. Little is known about how secretagogues such as $\mathrm{GnRH}$ or steroids affect their expression. Little is known how altering the activities of specific glycosyltransferases will affect the relative abundance of a desired glycan at various glycosylation sites in the protein. For example, if GnTase IV is overexpressed, will there be an increase in triantennary glycans at all 4 sites in FSH? Will LH glycans become predominantly triantennary or will they remain largely biantennary? Oligosaccharide mass spectrometry can address the relative abundance for the total glycan population. Once desired glycan abundance increases, a more demanding approach will be needed to define glycosylation at individual sites. Here, mass matching of glycopeptides combined with detailed analysis of total oligosaccharide preparations would probably provide sufficient detail for developmental studies. If uniformly glycosylated gonadotropins could be prepared, then experiments to compare relative activities are readily performed and could be used to design more effective gonadotropin preparations for clinical use.

Overexpression of GnTases would be useful to make recombinant hyperglycosylated hCG, which would be valuable as a standard for diagnostic assays for early pregnancy loss. The literature largely describes tumor-associated hyperglycosylated hCG and glycosylation differences exist. Detailed characterization of early pregnancy hyperglycosylated hCG Replacement therapy with hyperglycosylated hCG might become possible when low levels of this hormone are detected, once obvious difficulties with administration of a paracrine factor are overcome. It is possible intrauterine rather than systemic administration would be effective. The potential to stimulate cell invasion would have to be carefully evaluated and antagonists developed. Differences in glycosylation between young and menopausal women certainly suggests major differences in the post-translational modification pathways. Future studies should address whether di- and tetraglycosylated $\mathrm{hFSH}$ are effective as isolated glycoforms. As physiological samples almost invariably contain both glycoforms, normal reproductive function may require the presence of both glycoforms. Preparation of individual glycoforms is necessary even if both are needed, as it would be possible to vary the ratios of the two forms and test their efficacy. For example, in IVF protocols, it might be helpful to vary the ratio of the two forms during the period of hyperstimulation to reflect the physiology of younger, more fertile women. Identification of the protein, which recognizes the seven amino acid sorting signal in $\mathrm{hLH}$, and directs it to the induced secretion pathway would be of interest.

Acknowledgements The authors thank Le Studium for supporting the workshop that led to this article.

Open Access This article is distributed under the terms of the Creative Commons Attribution Noncommercial License which permits any noncommercial use, distribution, and reproduction in any medium, provided the original author(s) and source are credited.

\section{References}

1. Dias JA, Cohen BD, Lindau-Shepard B, Nechamen CA, Peterson AJ, Schmidt A. Molecular, structural, and cellular biology of follitropin and follitropin receptor. Vitamins and hormones. New York: Academic; 2002. p. 249-322.

2. Ascoli P, Cavagnini T. Hypopituitarism. Pituitary. 2006;9:335-42.

3. Cole LA. New discoveries on the biology and detection of human chorionic gonadotropin. Reprod Biol Endocrinol. 2009;7:8.

4. de Medeiros SF, Norman RJ. Human choriogonadotrphin protein core and sugar branches heterogeneity: Basic and clinical insights. Hum Reprod Update. 2009;15:69-95.

5. Bousfield GR, Jia L, Ward DN. Gonadotropins: chemistry and biosynthesis. In: Neill JD, editor. Knobil and Neill: Physiology of reproduction. 3rd ed. San Diego: Elsevier; 2006. p. 1581634.

6. Bernard DJ, Fortin J, Wang Y, Lamba P. Mechanisms of FSH synthesis: What we know, what we don't, and why you should care. Fertil Steril. 2010;93:2465-85.

7. Ciccone NA, Kaiser UB. The biology of gonadotroph regulation. Curr Opin Endocrinol Diabetes Obes. 2009;16(4):321-7.

8. Wu Y, Luo H, Liu J, Kang D, McNeilly AS, Cui S. LIM homeodomain transcription factor Isl-1 enhances folliclestimulating hormone-beta and luteinizing hormone-beta gene expression and mediatse the activation of leptin on gonadotropin synthesis. Endocrinology. 2010;151:4787-800.

9. Crawford JL, Heath DA, Haydon LJ, Thompson BP, Eckery DC. Gene expression and secretion of LH and FSH in relation to gene expression of GnRH receptors in the brushtail possum (Tricosurus vulpecula) demonstrates highly conserved mechanisms. Reproduction. 2009;137(1):129-40.

10. Knobil E. The neuroendocrine control of ovulation. Hum Reprod. 1988;3(4):469-72. 
11. Kanasaki H, Mutiara S, Oride A, Purwana IN, Miyazaki K. Pulse frequency-dependent gonadotropin gene expression by adenylate cyclase-activating polypeptide 1 in perifused mouse pituitary gonadotroph LbetaT2 cells. Biol Reprod. 2009;81(3):465-72.

12. Burger LL, Halsenleder DJ, Aylor KW, Marshall JC. Regulation of $\mathrm{LH} \alpha$ and Egr1 gene expression by $\mathrm{GnRH}$ pulses in rat pituitaries is both c-Jun N-terminal kinase (JNK)- and extracellular signal-regulated kinase (ERK)-dependent. Biol Reprod. 2009;81(6):1206-15.

13. Ciccone NA, Xu SY, Lacza T, Carroll RS, Kaiser UB. Frequencydependent regulation of follicle-stimulating hormone beta by pulsatile gonadotropin-releasing hormone is mediated by functional antagonism of bZIP transcription factors. Mol Cell Biol. 2010;30 (4): $1028-40$

14. Naor Z, Jabbour HN, Naidich M, Pawson AJ, Morgan K, Battersby $\mathrm{S}$, et al. Reciprocal cross talk between gonadotropin-releasing hormone $(\mathrm{GnRH})$ and prostaglandin receptors regulates $\mathrm{GnRH}$ receptor expression and differential gonadotropin secretion. Mol Endocrinol. 2007;21(2):524-37.

15. Lieblich JM, Weintraub BD, Rosen SW, Chou JY, Robinson JC. HeLa cells secrete alpha subunit of glycoprotein tropic hormones. Nature. 1976;260(5551):530-2.

16. Casella I, Lindner H, Zenzmaler C, Ritano D, Berger P, Costa T. Non-gonadotropin-releasing hormone-mediated transcription and secretions of large human glycoprotein hormone alpha-subunit in human embryonic kidney-293 cells. Endocrinology. 2008;149 (3): $1144-54$

17. Thackray VG, McGillivray SM, Mellon PL. Androgens, progestins, and glucocorticoids induce follicle-stimulating hormone betasubunit gene expression at the level of the gonadotrope. Mol Endocrinol. 2006;20(9):2062-79.

18. Thackray VG, Hunnicutt JL, Memon AK, Ghochani Y, Mellon PL. Progesterone inhibits basal and gonadotropin-releasing hormone induction of luteinizing hormone beta-subunit gene expression. Endocrinology. 2009;150(5):2395-403.

19. Szawka RE, Rodovalho GV, Monteiro PM, Carrer HF, AnselmoFranci JA. Ovarian-steroid modulation of Locus Coeruleus activity in female rats: Involvement in luteinising hormone regulation. J Neuroendocrinol. 2009;21(7):629-39.

20. Navarro VM, Tena-Sempere M. Kispeptins and the neuroendocrine control of reproduction. Front Biosci (Shol Ed). 2011;3:267-75.

21. Smith JT, Clarke IJ. Gonadotropin inhibitory hormone function in mammals. Trends Endocrinol Meta. 2010;21(4):255-60.

22. Clarke IJ. Control of GnRH secretion: one step back. Front Neuroendocrinol. 2011;Epub(Jan 7).

23. Ubuka T, Morgan K, Pawson AJ, Osugi T, Chowdry VS, Minakata $\mathrm{H}$, et al. Identification of human $\mathrm{GnIH}$ homologs, RFRP-1 and RFRP-3, and the congnate receptor, GPR147 in the human hypothalamic pituitary axis. PLoS One. 2009;4(12):e8400.

24. Carroll TS, Corrigan AZ, Gharib SD, Vale W, Chin WW. Inhibin, activin, follistatin - regulation of follicle-stimulating hormone messenger-ribonucleic-acid levels. Mol Endocrinol. 1989;3 (12):1969-76.

25. Nicol L, Faure MO, McNeilly JR, Fontaine J, Taragnat C, McNeilly AS. Bone morphogenetic protein-4 interacts with activin and GnRH to modulate gonadotrophin secretion in L beta T2 gonadotrophs. J Endocrinol. 2008;196(3):497-507.

26. Muller T, Simoni M, Pekel E, Luetjens CM, Chandolia R, Amato $\mathrm{F}$, et al. Chorionic gonadotrophin beta subunit mRNA but not luteinising hormone beta subunit mRNA is expressed in the pituitary of the common marmoset (Callithrix jacchus). J Mol Endocrinol. 2004;32(1):115-28.

27. Scammell JG, Funkhouser JD, Moyer FS, Gibson SV, Willis DL. Molecular cloning of pituitary glycoprotein $\alpha$-subunit and follicle stimulating hormone and chorionic gonadotropin $\beta$ - subunits from new world squirrel mnokey and owl monkey. Gen Comp Endocrinol. 2008;155(3):534-41.

28. Birken S, Maydelman Y, Gawinowicz MA, Pound A, Liu Y, Hartree AS. Isolation and characterization of human pituitary chorionic gonadotropin. Endocrinology. 1996;137(4):1402-11.

29. Hoshina H, Boime I. Combination of rat lutropin subunits occurs early in the secretory pathway. Proc Natl Acad Sci USA. 1982;79:7649-53.

30. Peters BP, Krzesicki RF, Hartle RJ, Perini F, Ruddon RW. A kinetic comparison of the processing and secretion of the $\alpha \beta$ dimer and the uncombined $\alpha$ and $\beta$ subunits of chorionic gonadotropin synthesized by human choriocarcinoma cells. J Biol Chem. 1984;259(24):15123-30.

31. Magner JA, Weintraub BD. Thyroid-stimulating hormone subunit processing and combination in microsomal subfractions of mouse pituitary tumor. J Biol Chem. 1982;257(12):6709-15.

32. Boothby M, Kukowaska J, Boime I. Imbalanced synthesis of human choriogonadotropin alpha and beta subunits reflects the steady state levels of the corresponding mRNAs. J Biol Chem. 1983;258(15):9250-3.

33. Dias JA. Endocrinology: Fertility hormone in repose. Nature. 2005;433(7023):203-4.

34. Krystek SR, Dias JA. Glycoprotein hormones tied but not tethered like other cysteine-knot cytokines. Trends Pharmacol Sci. 2005;26(9):439-42.

35. Lapthorn AJ, Harris DC, Littlejohn A, Lustbader JW, Canfield RE, Machin KJ, et al. Crystal structure of human chorionic gonadotropin. Nature. 1994;369:455-61.

36. Wu H, Lustbader JW, Liu Y, Canfield RE, Hendrickson WA. Structure of human chorionic gonadotropin at $2.6 \AA$ resolution from MAD analysis of the selenomethionyl protein. Structure. 1994;2:545-58.

37. Fox KM, Dias JA, Van Roey P. Three-dimensional structure of human follicle-stimulating hormone. Mol Endocrinol. 2001;15:378-89.

38. Xing Y, Myers R, Cao D, Lin W, Jiang M, Bernard M, et al. Glycoprotein hormone assembly in the endoplasmic reticulum: I. The glycosylated end of human alpha-subunit loop 2 is threaded through a beta-subunit hole. J Biol Chem. 2004;279(34):35426-36.

39. Xing Y, Myers R, Cao D, Lin W, Jiang M, Bernard M, et al. Glycoprotein hormone assembly in the endoplasmic reticulum: II. Multiple roles of a redox sensitive beta-subunit disulfide switch. J Biol Chem. 2004;279(34):35437-48.

40. Blithe DL. N-linked oligosaccharides on free $\alpha$ interfere with its ability to combine with human chorionic gonadotropin- $\beta$ subunit. J Biol Chem. 1990;265:21951-6.

41. Butnev VY, Gotschall RR, Butnev VY, Baker VL, Moore WT, Bousfield GR. Hormone-specific inhibitory influence of $\alpha$ subunit $\mathrm{Asn}^{56}$ oligosaccharide on in vitro subunit association and FSH receptor binding of equine gonadotropins. Biol Reprod. 1998;58(2):458-69.

42. Xing Y, Moyle WR. Efficient preparation of glycoprotein hormones lacking an alpha-subunit oligosaccharide. Biochem Biophys Res Commun. 2003;303(1):201-5.

43. Xing Y, Myers R, Cao D, Lin W, Jiang M, Bernard M, et al. Glycoprotein hormone assembly in the endoplasmic reticulum: III. The seatbelt and its latch site determine the assembly pathway. J Biol Chem. 2004;279(34):35449-57.

44. Xing Y, Myers R, Cao D, Lin W, Jiang M, Bernard M, et al. Glycoprotein hormone assembly in the endoplasmic reticulum: IV. Probable mechanism of subunit docking and completion of assembly. J Biol Chem. 2004;279(34):35458-68.

45. Jablonka-Shariff A, Pixley M, Boime I. Polarized secretion of gonadotropins by transfected MDCK cells. Mol Biol Cell. 2000;11:1654. 
46. Jablonka-Shariff A, Garcia-Campayo V, Boime I. Evolution of lutropin to chorionic gonadotropin generates a specific routing signal for apical release in vivo. J Biol Chem. 2002;277(2):879-82.

47. Jablonka-Shariff A, Boime I. Secretory trafficking signal encoded in the carboxyl-terminal region of the CG betasubunit. Mol Endocrinol. 2009;23(3):316-23.

48. Jablonka-Shariff A, Boime I. Luteinizing hormone and folliclestimulating hormone exhibit different secretion patterns from cultured Madin-Darby canine kidney cells. Biol Reprod. 2004;70 (3):649-55.

49. Jablonka-Shariff A, Pearl CA, Comstock A, Boime I. A carboxylterminal sequence in the lutropin beta subunit contributes to the sorting of lutropin to the regulated pathway. J Biol Chem. 2008;283 (17):11485-92.

50. Pearl CA, Jablonka-Shariff A, Boime I. Rerouting of a folliclestimulating hormone analog to the regulated secretory pathway. Endocrinology. 2010;151(1):388-93.

51. Robin E, Cognie J, Foulon-Gauze F, Fontaine J, Cayla X. Disruption of lipid rafts induces gonadotropin release in ovine pituitary and LbetaT2 gonadotroph cells. Biol Reprod. 2008;79 (1):17-25.

52. Weisshaar G, Hiyama J, Renwick AGC, Nimtz M. NMR investigations of the $\mathrm{N}$-linked oligosaccharides at individual glycosylation sites of human lutropin. Eur J Biochem. 1991;195:257-68.

53. Hudgin RL, Pricer Jr WE, Ashwell G, Stockert RJ, Morell AG. The isolation and properties of a rabbit liver binding protein specific for asialoglycoproteins. J Biol Chem. 1974;249:5536-43.

54. Morell AG, Gregoriadis G, Scheinberg IH, Hickman J, Ashwell G. The role of sialic acid in determining the survival of glycoproteins in the circulation. J Biol Chem. 1971;246:1461-7.

55. Lefort GP, Stolk JM, Nisula BC. Evidence that desialylation and uptake by hepatic receptors for galactose-terminated glycoproteins are immaterial to the metabolism of human choriogonadotropin in the rat. Endocrinology. 1984;115(4):1551-7.

56. Green ED, Baenziger JU. Asparagine-linked oligosaccharides on lutropin, follitropin, and thyrotropin II. Distributions of sulfated and sialylated oligosaccharides on bovine, ovine, and human pituitary glycoprotein hormones. J Biol Chem. 1988;263:36-44.

57. Damian-Matsumura P, Zaga V, Maldonado A, Sanchez-Hernandez C, Timossi C, Ulloa-Aquirre A. Oestrogens regulate pituitary $\alpha 2,3-$ sialyltransferase messenger ribonucleic acid levels in the female rat. J Mol Endocrinol. 1999;23:153-65.

58. Ambao V, Rulli SB, Carino MH, Console G, Ulloa-Aguirre A, Clandra RS, et al. Hormonal regulation of pituitary FSH sialylation in male rats. Mol Cell Endocrinol. 2009;309(1-2):39-47.

59. Fiete D, Srivastava V, Hindsgaul O, Baenziger JU. A hepatic reticuloendothelial cell receptor specific for $\mathrm{SO}_{4}-4 \mathrm{Gal}$ NAc $\beta 1,4 \mathrm{GlcNAc} \beta 1,2 \mathrm{Man} \alpha$ that mediates rapid clearance of lutropin. Cell. 1991;67:1103-10.

60. Pearl CA, Boime I. Sulfation of LH does not affect intracellular trafficking. Mol Cell Endocrinol. 2009;309(1-2):76-81.

61. Green ED, Baenziger JU. Asparagine-linked oligosaccharides on lutropin, follitropin, and thyrotropin: I. structural elucidation of the sulfated and sialylated oligosaccharides on bovine, ovine and human pituitary glycoprotein hormones. J Biol Chem. 1988;263:25-35.

62. Dalpathado DS, Irungu JA, Go EP, Butnev VY, Norton K, Bousfield GR, et al. Comparative glycomics of the glycoprotein hormone follicle-stimulating hormone (FSH): Glycopeptide analysis of isolates from two mammalian species. Biochemistry. 2006; 45(28):8665-73.

63. Klett D, Bernard S, Lecompte F, Leroux H, Magallon T, Locatelli A, et al. Fast renal trapping of porcine luteinizing hormone $(\mathrm{pLH})$ shown by $123 \mathrm{I}$-scintigraphic imaging in rats explains its short circulatory half-life. Reprod Biol Endocrinol. $2003 ; 1: 64$.

64. Gervais A, Hammel Y-A, Pelloux S, Lepage P, Baer G, Carte N, et al. Glycosylation of human recombinant gonadotrophins: Characterization and batch-to-batch consistency. Glycobiology. 2003;13(3):179-89.

65. Hard K, Mekking A, Damm JB, Kammerling JP, De Boer W, Wijnands RA, et al. Isolation and structure determination of the intact sialylated $\mathrm{N}$-linked carbohydrate chains of recombinant human follitropin expressed in Chinese hamster ovary cells. Eur J Biochem. 1990;193(1):263-71.

66. Porchet HC, Le Cotonnec JY, Neuteboom B, Canali S, Zanolo G. Pharmacokinetics of recombinant human luteinizing hormone after intravenous, intramuscular, and subcutaneous administration in monkeys and comparison with intravenous administration of pituitary human luteinizing hormone. J Clin Endocrinol Metab. 1995;80(2):667-73.

67. Bousfield GR, Butnev VY, Bidart JM, Dalpathado D, Irungu J, Desaire H. Chromatofocusing fails to separate $\mathrm{hFSH}$ isoforms on the basis of glycan structure. Biochemistry. 2008;47(6):1708-20.

68. Bousfield GR, Butnev VY, Walton WJ, Nguyen VT, Singh V, Hueneidi J, et al. All or none $\mathrm{N}$-glycosylation in primate folliclestimulating hormone $\beta$ subunits. Mole Cell Endocrinol. 2007;260-262:40-8.

69. Renwick AGC, Mizuochi T, Kochibe N, Kobata A. The asparagine-linked sugar chains of human follicle-stimulating hormone. J Biochem. 1987;101:1209-21.

70. Harduin-Lepers A, Mollicone R, Delannoy P, Oriol R. The animal sialyltransferases and sialyltransferase-related genes: A phylogenetic approach. Glycobiology. 2005;15(8):80517.

71. Wheeler SF, Domann P, Havey DJ. Derivatization of sialic acids for stabilization in matrix-assistes laser desorption/ionization mass spectrometry and concomitant differentiation of $\alpha(2-3)$ and $\alpha(2-6)$-isomers. Rapid Commun Mass Spectrom. 2009;23:303-12.

72. Wheeler SF, Domann P, Harvey DJ. Derivatization of sialic acids for stabilization in matrix-assisted laser desorption/ionization mass spectrometry and concomitant differentiation of alpha(2 $->3)$ - and alpha(2 ->6)-isomers. Rapid Commun Mass Spectrom. 2009;23 (2):303-12. doi:10.1002/rcm.3867.

73. Chavan M, Lennarz W. The molecular basis of coupling of translocation and N-glycosylation. Trends Biochem Sci. 2006;31 (1): $17-20$.

74. Kelleher DJ, Gilmore R. An evolving view of the eukaryotic oligosaccharyltransferase. Glycobiology. 2006;16(4):47R-62.

75. Walton WJ, Nguyen VT, Butnev VY, Singh V, Moore WT, Bousfield GR. Characterization of human follicle-stimulating hormone isoforms reveals a non-glycosylated $\beta$-subunit In addition to the conventional glycosylated $\beta$-subunit. J Clin Endocrinol Metab. 2001;86:3675-85.

76. Yan A, Lennarz WJ. Unraveling the mechanism of protein Nglycosylation. J Biol Chem. 2005;280(5):3121-4.

77. Ruiz-Canada C, Kelleher DJ, Gilmore R. Cotranslational and posttranslational $\mathrm{N}$-glycosylation of polyppetides by distinct mammalian OST isoforms. Cell. 2009;136(2):272-83.

78. Chavan M, Chen Z, Li G, Schindelin H, Lennarz WJ, Li H. Dimeric organization of the yeast oligosaccharyl transferase complex. Proc Natl Acad Sci USA. 2006;103(24):8947-52.

79. Park H, Lennarz WJ. Evidence for interaction of yeast protein kinase $\mathrm{C}$ with several subunits of oligosaccharyl transferase. Glycobiology. 2000;10(7):737-44.

80. Yan A, Lennarz W. Two oligosaccharyl tranferase complexes exist in yeast and associate with two different translocons. Glycobiology. 2005;15(12):1407-15. 
81. Kelleher DJ, Karaoglu D, Mandon EC, Gilmore R. Oligosaccharyltransferase isoforms that contain different catalytic STT3 subunits have distinct enzymatic properties. Mol Cell. 2003;12:101-11.

82. Muyan M, Ryzmkiewicz DM, Boime I. Secretion of lutropin and follitropin from transfected $\mathrm{GH} 3$ cells: Evidence for separate secretory pathways. Mol Endocrinol. 1994;8:1789-97.

83. Helenius A, Aebi M. Roles of N-linked glycans in the endoplasmic reticulum. Annu Rev Biochem. 2004;73:1019-49.

84. Ioffe E, Stanley P. Mice lacking N-acetylglucosaminyltransferase I activity die at mid-gestation, revealing an essential role for complex or hybrid N-linked carbohydrates. Proc Natl Acad Sci USA. 1994;91(2):728-32.

85. Williams SA, Stanley P. Oocyte -specific deletion of complex and $\mathrm{N}$-glycans leads to defects in preovulatory and cumulus mass development. Reproduction. 2009;137:321-31.

86. Wang Y, Tan J, Sutton-Smith M, Ditto D, Panico M, Campbell RM, et al. Modeling human congenital disorder of glycosylation type IIa in the mouse: Conservation of asparagine-linked glycan-dependent functions in mammalian physiology and insights into disease pathogenesis. Glycobiology. 2001;11(12):1051-70.

87. Song Y, Aglipay JA, Goswami S, Stanley P. The bisecting GlcNAc on $\mathrm{N}$-glycans inhibits growth factor signaling and retards mammary tumor progression. Cancer Res. 2010;70(8):3361-71.

88. Pinho SS, Teis CS, Paredes J, Magalhaes AM, Ferreira AC, Figueiredo $\mathrm{J}$, et al. The role of $\mathrm{N}$-acetylglycosaminyltransferase III and $\mathrm{V}$ in post-transcriptional modifications of E-cadherin. Hum Mol Genet. 2009;18(14):2599-608.

89. Walzel H, Brock J, Pohland R, Vanselow J, Tomek W, Schneider $\mathrm{F}$, et al. Effects of galectin-1 on regulation of progesterone production in granulosa cells from pig ovaries in vitro. Glycobiology. 2004;14(10):871-81.

90. Takamatsu S, Antonopoulos A, Ohtsubo K, Ditto D, Chiba Y, Le DT, et al. Physiological and glycomic characterization of Nacetylglycosaminyltransferase-IVa and -IVb double deficient mice. Glycobiology. 2010;20(4):485-97.

91. Dennis JW, Pawling J, Cheung P, Partdige E, Demetriou M. UDP-N-acetylglucosamine: Alpha-6-D-mannoside beta1,6 Nacetylglucosaminyltransferase V (Mgat5) deficient mice. Biochim Biophys Acta. 2002;1573(3):414-22.

92. Kaneko M, Alvarez-Manilla G, Kamar M, Lee I, Lee JK, Troupe $\mathrm{K}$, et al. A novel beta(1,6)-N-acetylglucosaminyltransferase $\mathrm{V}$ (GnT-VB)(1). FEBS Lett. 2003;554(3):515-9.

93. Cole LA. Biological functions of hCG and hCG-related molecules. Reprod Biol Endocrinol. 2010;8:102.

94. Guibourdenche J, Handschuh K, Tsatsaris V, Gerbaud P, Leguy MC, Muller F, et al. Hyperglycosylated hCG is a marker of early human trophoblast invasion. J Clin Endocrinol Metab. 2010;95(10):E240-4.

95. Handschuh K, Guibourdenche J, Tsatsaris V, Guesnon M, Laurendeau I, Evain-Brion D, et al. Human chorionic gonadotropin produced by the invasive trophoblast but not the villous trophoblast promotes cell invasion and is down-regulated by peroxisome proliferator-activated receptor-gamma. Endocrinology. 2007;149(10):5011-9.

96. Kovalevskaya G, Birken S, Kakuma T, Ozaki N, Sauer M, Lindheim S, et al. Differential expression of human chorinonic gonadotropin (hCG) glycosylation isoforms in failing and continuing pregnancies: Preliminary characterization of the hyperglycosylated hCG epitope. J Endocrinol. 2002;172:497506.

97. Valmu L, Alfthan H, Hotakainen K, Birken S, Stenman UH. Site-specific glycan analysis of human chorionic gonadotropin beta-subunit from malignancies and pregnancy by liquid chromatography-electrospray mass spectrometry. Glycobiology. 2006;16(12):1207-18.

98. Schaaf L, Leiprecht A, Saji M, Huber U, Usadel KH, Kohn LD. Glycosylation variants of human TSH selectively activate signal transduction pathways. Mol Cell Endocrinol. 1997;132:185-94.

99. Ulloa-Aguirre A, Maldonado A, Damian-Matsumura P, Timossi C. Endocrine regulation of gonsdotropin glycosylation. Arch Med Res. 2001;32(6):520-32.

100. Barrios-De-Tomasi J, Timossi C, Merchant H, Quintanar A, Avalos JM, Andersen CY, et al. Assessment of the in vitro and in vivo biological activities of the human follicle-stimulating hormone. Mol Cell Endocrinol. 2002;186(2):189-98.

101. Andersen CY, Westergaard LG, van Wely M. FSH isoform composition of commercial gonadotrophin preparations: A neglected aspect? Reprod Biomed Online. 2004;9(2):231-6.

102. Campo S, Ambao V, Creus S, Gottlieb S, Vera GS, Benencia H, et al. Carbohydrate sensitivity and proportions of serum FSH isoforms in the male; lectin-based studies. Mol Cell Endocrinol. 2007;260:197-204

103. Adams TE, Boime I. The expanding role of recombinant gonadotropins in assisted reproduction. Reprod Domest Anim. 2008;43:186-92.

104. Nagorny P, Fasching B, Li XC, Chen G, Aussedat B, Danishefsky SJ. Toward fully synthetic homogeneous betahuman follicle-stimulating hormone (beta-hFSH) with a biantennary N-linked dodecasaccharide. Synthesis of beta-hFSH with chitobiose units at the natural linkage sites. J Am ChemSoc. 2009;131(16):5792-9.

105. Wehbi V, Tranchant T, Durand G, Musnier A, Decourtye J, Piketty V, et al. Partially deglycosylated equine LH preferentially activates $\beta$-arrestin-dependent signaling at the folliclestimulating hormone receptor. Mol Endocrinol. 2010;24 (3):561-73.

106. Berman HH, Westbrook J, Feng Z, Gilliland G, Bhat TN, Weissig $\mathrm{H}$, et al. The protein data bank. Nucleic Acids Res. 2000;28:235-42.

107. Ruddon RW, Sherman SA, Bedows E. Protein folding in the endoplasmic reticulum: Lessons from the human chorionic gonadotropin $\beta$ subunit. Protein Sci. 1996;5:1443-52.

108. Weisshaar G, Hiyama J, Renwick AGC. Site-specific Nglycosylation of human chorionic gonadotropin-structural analysis of glycopeptides by one- and two-dimensional $1 \mathrm{H}$ NMR spectroscopy. Glycobiology. 1991;1(4):393-404.

109. Harvey DJ, Merry AH, Royle L, Campbell MP, Dwek RA, Rudd PM. Proposal for a standard system for drawing structural diagrams of $\mathrm{N}$ - and O-linked carbohydrates and related compounds. Proteomics. 2009;9(15):3796-801.

110. Taylor ME, Drickamer K. Introducton to glycobiology. 3rd ed. New York: Oxford University Press; 2011. 